\title{
Yenidoğan Yoğun Bakım Hemşirelerinin Motivasyonları Üzerine Niteliksel Bir Araştırma $\infty$
}

\author{
Mukaddes DEMiR ACAR ${ }^{1}$, Elif BULUT ${ }^{2}$
}

\section{Öz}

Amaç: Bu araştırma, bir üniversite hastanesi yenidoğan yoğun bakım ünitesinde (YYBÜ) görev yapan hemşirelerin motivasyonlarını belirlemek amacı ile yapıldı.

Gereç ve Yöntem: Araştırma nitel yöntemle, Mayıs-Haziran 2020 tarihleri arasında 10 yenidoğan yoğun bakım hemşiresi ile yapıldı. Veriler birebir derinlemesine görüşme tekniği ile toplandı. Görüşmelerde yarı yapılandııımış görüşme formu kullanıldı ve ses kaydı yapıldı. Görüşmelerden elde edilen veriler nitel içerik analizi yöntemiyle değerlendirildi.

Bulgular: Çalışmaya katılan hemşirelerinin yaş ortalaması 26, YYBÜ'de çalışma yılı ortalaması 4.5 yıl ve tümü kadındır. YYBÜ hemşireleri ile derinlemesine yapılan görüşmelerin içerik analizi sonucu iki ana tema ortaya çıkarıldı. Illk temanın "Başarı" ve alt temaların bebek sevgisi, deneyim, toparlanma olduğu, ikinci temanın ise "Yönetim" ve alt temaların ise aile, ekip, iş yükü olduğu belirlenmiştir.

Sonuç: Hemşirelerin bebek sevgisinin ve bebeklerin iyileşme bulguları göstermesinin motivasyonlarını arttırdığı ancak ekip, iletişimden kaynaklı sorunlar ve iş yükünün getirdiği güçlüklerin motivasyonlarını azalttığı belirlenmiştir. Çözümlenebilir nitelikte olan bu güçlüklerin ve sistem kaynaklı sorunların minimalize edilmesi için ekip çalışmasının benimsenmesi önerilmektedir.

Anahtar kelimeler: Hemşire, motivasyon, nitel araştırma, yenidoğan, yoğun bakım

\begin{abstract}
A Qualitative Study on the Motivations of Neonatal Intensive Care Nurses

Aim: This study was carried out to determine nurses' motivations working in a neonatal intensive care unit (NICU) of a university hospital.

Material and Methods: The research was conducted qualitatively with ten neonatal intensive care nurses between May and June 2020. The data were collected through one-on-one interview technique. During the interviews, a semi-structured interview form was used, and an audio recording was made. The data obtained from the interviews were evaluated with the qualitative content analysis method.

Results: The average age of the nurses participating in the study is 26 , the average working year in the NICU is 4.5 years, and all of them are women. As a result of the content analysis of the in-depth interviews with NICU nurses, two main themes were revealed. It was determined that the first theme was "Success" and sub-themes were baby love, experience, recovery, and the second theme was "Management" and sub-themes were family, team, and workload. Conclusion: It was determined that nurses' love of babies and showing signs of improvement of babies increase their motivations, but the problems caused by the team, communication, and workload difficulties reduce their motivations. It is recommended to adopt teamwork to minimize these difficulties and systemrelated issues.
\end{abstract}

Keywords: Intensive care, motivation, newborn, nurse, qualitative research

${ }^{1}$ Dr. Öğr. Üyesi, Tokat Gaziosmanpaşa Üniversitesi Sağlık Bilimleri Fakültesi, Hemşirelik, Tokat, Türkiye, E-posta: mukaddesdemir.acar@gop.edu.tr, Tel: 05055790222, ORCID: 0000-0002-6376-2171

${ }^{2}$ Arş. Gör., Karadeniz Teknik Üniversitesi Sağlık Bilimleri Fakültesi, Hemşirelik, Trabzon, Türkiye, E-posta: elifbulut@ktu.edu.tr, Tel: 05466681993, ORCID: 0000-00019124-2168

Geliş Tarihi: 09 Ağustos 2020, Kabul Tarihi: 05 Mayıs 2021

Atıf/Citation: Demir Acar M, Bulut E. Yenidoğan Yoğun Bakım Hemşirelerinin Motivasyonları̈ Üzerine Niteliksel Bir Araştırma. Hacettepe Üniversitesi Hemşsirelik Fakültesi Dergisi 2021;8(2):223-230. DOI: 10.31125/hunhemsire.968914 


\section{Giriş}

Bir güdü etkisiyle amaca yönelme, harekete geçme ve süreklilik sağlama süreci olan motivasyon (güdülenme), çeşitli uyarıııların etkisi ile kişilerin belirli bir amacı gerçekleştirmek üzere kendi istekleri ile davranmalarıdır ${ }^{1}$. Bir örgütte çalışanların verimliliklerini, etkinliklerini, üretkenliklerini, yaratıcılıklarını ve performanslarını etkileyen motivasyon, olumlu veya olumsuz yönde etkilenebilmektedir ${ }^{2,3}$. Çalışanların motivasyonunu etkileyen pek çok faktör bulunmaktadır. Bu faktörler ödül, ücret gibi ekonomik faktörler, değer, statü, başarı gibi psikososyal faktörler ve iletişim, otonomi, ekip çalışması, kararlara katılma gibi yönetsel-örgütsel faktörler şeklinde sıralanmaktadır ${ }^{4}$. Özellikle merkezinde insan/aile olan ve çok sayıda profesyonelin bir arada çalıştığı, karmaşık iş yüküne sahip hastanelerde, çalışanların motivasyonu kaliteli bir hizmet sunumunu açısından oldukça önemlidir ${ }^{5}$. Yoğun bakım ünitelerinde çalışan hemşireler gerek stresli iş ortamı gerekse yoğun çalışma temposu nedeniyle tükenmişlik açısından en riskli gruplardan birisidir. Bu durum, yoğun bakım hemşirelerinin kendine olan güvenlerini azaltırken anksiyetelerini arttırmakta ve mesleki motivasyonlarını düşürmektedir. Bu nedenle yoğun bakım hemşirelerinin çalışma ortamlarının gözden geçirilerek, mesleki motivasyonlarının arttırılması için yenilikçi girişimsel stratejiler oluşturulmalıdır ${ }^{6}$.

Yenidoğan yoğun bakım ünitelerinde (YYBÜ) annenin, bebeğinin prematüre ve/veya fiziksel gelişim problemi gibi ciddi sağlık sorunlarının olması ya da istenmemesi, annelik rolünün benimsenmesini zorlaştırarak anne-bebek bağlanmasını güçleştirmektedir ${ }^{7-9}$. YYBÜ'de bebeği yatan annelerin değerlendirildiği nitel bir araştırmada annelerin yoğun üzüntü, suçluluk, kaygı yaşadıkları, bu duygular ile başa çıkmakta zorlandıkları, aile hayatında ki değişimlerden olumsuz etkilendikleri, hemşireler ve kendi ailelerinden destek beklentileri olduğu belirlenmiştir ${ }^{10}$. Ebeveynler sağlıklı bir bebek beklerken erken doğmuş ve/veya fiziksel gelişim bozukluğu olan bir bebeğin doğumu ile kayıp yaşadıkları bu süreçte sağlık ekibinin deneyimli tedavi ve bakımının yanı sıra uygun bir iletişime de gereksinim duyarlar. Hemşireler, yaşam döngüsünde, iyilikten hastalığa geçiş, gebelik, doğum, annelik gibi rol değişimlerinde bireylerle en sık etkileşim içinde olan, rol değişim sürecinde bireylerin psikososyal ihtiyaçlarını en iyi değerlendirebilecek, gereksinimlerine göre bireysel ve bütüncül bakımı verebilecek yakınlıkta sağlık profesyonelleridir ${ }^{9,11}$. Hemşirelerden beklenen düzeyde verimin elde edilmesi ve sağık hizmetinin istenen kalitestandartta verilebilmesi için, hemşirelerin beklentilerinin bilinmesi, sorunlarının belirlenerek çözümlenmesi, motivasyonu olumlu yönde etkileyen kaynakların desteklenmesi gerekmektedir ${ }^{12,13}$. Özellikle yoğun bakım gibi iş yükünün ve sorumluluğun daha ağır olduğu birimlerde motivasyonun önemi oldukça büyüktür. Sağlık hizmetlerinde hedeflenen hemşirelik hizmetinin verilebilmesinin ancak motivasyonu yüksek hemşirelerle mümkün olduğu bilinmektedir ${ }^{12}$.
Hastanelerde sağlık ekibinin tüm eylemleri, hastanın en kısa zamanda sağlığına kavuşturulmasına odaklıdır. Ekip çalışmasının yeterli olmadığı birimlerde tanı ve tedavi işlemlerinde gecikme, hasta hakkında çelişkili bilgilere sahip olma, hizmet kalitesinin düşmesi gibi sorunlar meydana gelebilmektedir ${ }^{14}$. Bir ekibin başarılı olabilmesi için öncelikle, ekip üyelerinin ekibin amacını, ekip liderliğini, ekip içindeki kendi rolünü, diğer üyeleri ve rollerini, çalışmanın kendine sağlayacağı yararları bilmesi gerekir ${ }^{15}$. Motivasyon ise bir ekibin başarısını etkileyen en önemli faktörlerden biridir. Günümüzde insanları motive etmek, çalışanların yeteneklerini artırmak, bilgi paylaşımlarını sağlamak ve performanslarını yükseltmek için ekip çalışmasına önem verilmektedir. Bir araştırmada hemşirelerin motivasyon düzeyi ile ekip çalışması arasında anlamlı bir ilişki olduğu belirlenmiştir ${ }^{16}$. Literatüre bakıldığında sağlık ekibi içerisinde sayıca çoğunlukta olan hemşirelerin motivasyonlarının incelenmesine yönelik nitel araştırmaların sınırlı olduğu daha çok nicel araştırma tasarımının yer aldığı görülmüştür.

\section{Araştırmanın Amacı}

$\mathrm{Bu}$ araştırmada yenidoğan yoğum bakım hemşirelerinin motivasyonlarının nitel araştırma yöntemi ile araştırılması amaçlanmaktadır.

\section{GEREÇ ve YÖNTEM}

\section{Araştırmanın Türü}

Yenidoğan yoğun bakım ünitesinde çalışan hemşirelerin, motivasyonlarının belirlenmesi amacıyla fenomonolojik tasarımla yapılmıştır.

\section{Araştırma Evren ve Örneklemi}

Araştırmanın evrenini bir üniversite hastanesinin YYBÜ'sinde çalışan 24 hemşire oluşturmuştur.

Örneklem seçiminde amaca yönelik örneklem yöntemlerinden biri olan ölçüt örnekleme kullanılmıştır. Araştırmaya dahil edilme kriterleri; hemşirelik lisans mezunu olmak, en az bir yıldır YYBÜ'de çalışmak olarak belirlenmiştir. YYBÜ'de çalışan 18 hemşirenin araştırmaya dahil edilme kriterlerine uyduğu, 6 hemşirenin ise uymadığı bulunmuştur. Araştırmaya dahil edilme kriterlerine uyan hemşirelerden 4'ünün araştırmanın yapıldığı tarihlerde izinde olduğu, 4'ünün ise araştırmaya katılmayı kabul etmediği belirlenmiştir. Bu kapsamda araştırmaya katılmaya gönüllü olan toplam 10 hemşire araştırmanın örneklemini oluşturmuştur. Amaca yönelik örneklem büyüklüğü yöntemine göre, yeni bilgiler ortaya çıkmadığında, veriler tekrar etmeye başladığında ve doyum noktasına ulaştığında veri toplama süreci sonlandırılmıştır.

\section{Araştırmanın Yapıldığı Yer ve Özellikleri}

Araştırma, Türkiye'de Orta Karadeniz Bölgesinde bir ilin Üniversite Hastanesi YYBÜ'de yürütülmüştür. Hastanede çocuk servisi, çocuk yoğun bakım, çocuk acil, doğum salonu, kadın doğum servisi gibi anne ve çocuğa ilişkin kliniklerin yanı sıra dahili ve cerrahi diğer klinikler de yer almaktadır. Hastane, bebek dostu hastane niteliğinde hizmet vermektedir. YYBÜ, 16 adet üçüncü basamak, 5 adet ikinci basamak olmak üzere 21 yatak kapasitesindedir ve 24 hemşire, 3 ebe, 4 uzman doktor, 11 araştırma görevlisi doktor görev yapmaktadır. 


\section{Veri Toplama Araçları}

Nitel araştırma; insanların yaşam tarzları, gözlemleri, duyguları, davranışları, bilgi ve deneyimlerini çok boyutlu ve detaylı olarak anlamayı amaçlamaktadır ${ }^{17}$. Nitel araştırma desenleri arasında yer alan fenomonolojik (olgu bilim) desen, bireyin farkında olduğu ancak derinlemesine ve ayrıntılı bir anlayışa sahip olmadığı olgulara odaklanmaktadır. Fenomonolojik araştırmalar nitel araştırmanın doğasına uygun olarak kesin ve genellenebilir sonuçlar ortaya koymayabilir. Ancak bir olguyu daha iyi tanımamıza ve anlamamıza yardımcı olacak sonuçlar sağlayacak örnekler, açıklamalar ve yaşantılar ortaya koyabilir. Bu yönüyle hem bilimsel literatüre hem de uygulamaya önemli katkılar getirebilir ${ }^{18,19}$.

Bu çalışmada, YYBÜ'de görev yapan hemşirelerin motivasyonlarını etkileyen faktörleri onların yaşantıları, örnekleri ve açıklamaları ile belirlemek, derinlemesine veri toplamak amaçlandığı için fenomonolojik desende nitel yöntem kullanıldı. Araştırma verileri, "Yarı Yapılandırılmış Görüşme Formu" kullanılarak toplandı. Görüşme formunun iç geçerliğini sağlamak için bir hemşire ile ön uygulama yapıldı ve konuyla ilgili iki uzman akademisyenin görüşü alınarak önerileri doğrultusunda sorulara son şekli verildi. $\mathrm{Bu}$ sorular; Yenidoğanlara bakım verme/ yenidoğan hemşireliği nasıl bir duygu açıklar mısınız? Mesleğinizde sizi mutlu eden, motivasyonunuzu arttıran, mesleki doyum sağlayan durumları açıklar mısınız? Mesleğinizi uygularken yaşadığınız güçlükler nelerdir? Motivasyonunuzu azaltan faktörler nelerdir? Açıklar mısınız?

\section{Verilerin Toplama Araçlarının Uygulanması}

Sonraki aşamada katılımcılardan görüşmeler için randevu alındı. Randevular oluşturulurken hemşirelerin tercihleri ve uygun zamanları dikkate alındı. Her hemşire ile görüşme yaklaşık yarım saat sürdü. Görüşmeler sırasında katılımcılardan izin alınarak ses kaydı yapıldı. Hemşirelerle görüşmeler, YYBÜ'de yer alan sessiz bir klinik hemşire odasında, daha önceden nitel araştırma kursuna katılmış olan birinci araştırmacı tarafından yapıldı. Araştırmacı birebir derinlemesine görüşmeler sırasında katılımcıların görüşlerini rahatça ifade edebilecekleri bir ortam sağladı. Ayrıca veri toplamanın hemen sonunda araştırmacı, topladığı verileri özetleyerek, katılımcıların bunların doğruluğuna ilişkin düşüncelerini belirtmesini istemiş ve böylece inanılırlığını (credibility) arttırmada katılımc teyidi stratejisi sağlanmıştır ${ }^{19,20 .}$

\section{Verilerin Analizi}

Birebir derinlemesine görüşmelerden elde edilen veriler, nitel veri analizi yöntemlerinden biri olan içerik analizi yöntemiyle değerlendirildi. İçerik analizi, toplanan verilerin derinlemesine analiz edilmesini gerektirir ve önceden belirgin olmayan temaların ve alt temaların ortaya çıkarılmasını sağlar. İçerik analizinde temelde yapılan işlem, birbirine benzeyen verileri belirli kavramlar ve temalar çerçevesinde bir araya getirmek ve bunları okuyucunun anlayabileceği bir biçimde düzenleyerek yorumlamaktır ${ }^{18,19}$. $\mathrm{Bu}$ çalışmada birebir derinlemesine görüşmeler bittikten sonra ses kayıtları araştırmacılar tarafından tekrar dinlenerek katılımcıların söyledikleri şekliyle aynen bilgisayar ortamında yazıldı ve böylece veri seti oluşturuldu. İçerik analizinin ilk aşaması olan verilerin kodlanması aşamasında Tablo 1'de belirtilen kodlar oluşturuldu. Bu amaçla, veri setinde yazılan ifadeler tekrar tekrar okundu, aynı, benzer ve farklı ifadeler gruplandırıldı. İkinci aşama olan tematik kodlamada ise ilk aşamada ortaya çıkan kodlardan yola çıkarak verileri, genel düzeyde açıklayabilen ve kodları belirli kategoriler altında toplayabilen alt temalar bulundu. Gruplandırılan ifadeler kendi içinde tekrar değerlendirildi ve en çok tekrarlanan ifadeler belirlenerek araştırmanın ana temaları oluşturuldu. Verilerin kodlara ve temalara göre düzenlenmesi ve tanımlanmasından sonra bulgular yorumlandı. Böylece toplanan verilere anlam kazandırıldı, bulgular arasındaki ilişkiler açıklandı, nedensonuç ilişkileri kuruldu ve bulgulardan sonuçlar oluşturuldu. Verilerin analizini her iki araştırmacı ve iki uzman birlikte tartışarak, uzlaşarak ve karar vererek yaptı. Böylece çalışmanın güvenilirlik ve iç geçerliliğini artırmada araştırmacı üçgenleme stratejisi sağlandı ${ }^{18-20}$. İçerik analizinde iki ana tema ve altı alt tema belirlendi (Tablo 1).

\section{Araştırmanın Etik Boyutu}

Araştırma, Helsinki Deklerasyonu Prensipleri, Araştırma ve Yayın Etiğine uygun olarak yürütüldü. Çalışmaya başlamadan önce kurum izni ve etik kurul izni alındı (Karar no:2020/01-11). Daha sonra YYBÜ'de çalışan katılımcılara (K) çalışmanın amacı, yöntemi ve gönüllülük ilkesi konusunda açıklama yapıldıktan sonra "Bilgilendirilmiş Onam Formu" kullanılarak yazılı ve sözlü onam alındı. Görüşmelerin ses kayıt cihazına kayıt edilmesi ile ilgili hemşirelerden izin alındı.

\section{Araştırmanın Sınırlılıkları}

Araştırmanın, yenidoğan yoğun bakım ekibi içindeki diğer sağlık profesyonellerini kapsamaması araştırmanın bir sınırıılığıdır. Ayrıca amaca yönelik örneklem büyüklüğü yöntemlerinden biri olan ölçüt örnekleme göre dizayn edilen bu çalışmada, katılımcılarla yapılan birebir derinlemesine görüşmelerde, yeni bilgiler ortaya çıkmadığında, veriler tekrar etmeye başladığında ve doyum noktasına ulaştığında veri toplama süreci sonlandırılmıştır. Buna rağmen araştırmanın YYBÜ'de çalışan tüm hemşireleri kapsamaması, araştırmanın sınırlılıkları içerisinde yer almıştır.

\section{BULGULAR}

Çalışmaya katılan yenidoğan hemşirelerinin yaş ortalaması 26, tümü kadın ve yenidoğan yoğun bakım hemşireliği deneyimlerinin ortalama 4.5 yıl olduğu belirlendi. Araştırmanın ana ve alt temalarına yönelik elde edilen bulgular;

Tema 1. Başarı: Bebek sevgisi, deneyim, toparlanma YYBÜ hemşireleri ile derinlemesine yapılan görüşmelerin içerik analizi sonucu ilk temanın "Başarı" ve alt temaların bebek sevgisi, deneyim, toparlanma olduğu görülmektedir. Bebek sevgisi alt temasını oluşturan kodların; annelik duygusu, kendi bedeninde onu hissetme, mutlu olma, deneyim alt temasının; karar verme, özgüven, dikkat olduğu ve toparlanma alt temasının ise; kilo alıp toparlanma, günden güne düzelme, solunum desteğinde azalma, iyileşme, taburcu olma kodlarından oluştuğu görülmektedir 
(Tablo 1). Yenidoğan hemşireleri, sevgi ve ilginin yanı sıra yeterli ve özenli bir hemşirelik bakımı ile bebeklerin iyileşme ve taburcu olmalarına katkı sağladıklarını belirtiyorlardı. YYBÜ'nin ayrıcalıklı bir bölüm olması nedeniyle bebeğin bir üst basamağa/sınıfa geçmesinde bakım, karar verme ve dikkatli izlemin deneyimle ilgili olduğuna da dikkat çekiyorlardı. Böylece topluma sağlıklı bireyler kazandırmak ve anne ile bebeğin mutlu olmasına katkı sağlamakla başarma duygularının ve motivasyonlarının arttığı belirlendi.

\section{Alt Tema 1. Bebek sevgisi}

Bir bebeğin gazını çıkarırken yakın temas halinde olduğumuz zaman o bebeğin nefes alışverişini hissetmek, kalp atışını hissetmek ve kendi bedeninde onu hissetmek ayrı bir duygu. K-4

Kliniği kötü seyreden bir bebeğin bakımımızla, sevgimizle, ilgimizle, şefkatimizle toparladığını görmek, iyiye gittiğini görmek, beni oldukça motive ediyor. $\mathrm{K}-\mathrm{9}$

Yenidoğanı anlamak için yenidoğan ortamında bulunmak Iazım, işini sevmek lazım her şeyden önce ve bebek sevmek lazım bence. $\mathrm{K}-5$

O bebeklerin büyüdüğünü görüp geri dönüşünü almak, telefonlaştığımı aileler var onların böyle dönem dönem fotoğraflarını attıklarını gördügümmüz, tabi bunlar mesleki doyum sağlıyor. $K-2$

Onlara dokunmak bir kere hani bebek olmasının verdiği minimal şeyleri seviyoruz malum, onun verdiği duygu çok başka, bir de hepimiz kadınız annelik duygusu var o yüzden yenidoğanda çalışmayı seviyorum. $K-7$

\section{Alt Tema 2. Deneyim}

Bu klinikte bir orogastrik takmakta bile gerçekten bir yılla altı yılın arasında çok fark var. Bu iş gerçekten basitmiş gibi gözükebilir ama birinci yılda ya da ilk deneyimde ağrılı yapıp belki de hani o bebeğin ağzını tutmak bile nasıl bir baskı uygulayacağınızı bilmiyorsunuz. Ama altıncı yıldan sonra gerçekten her şey yani o süreç gerçekten evrimleşmiş oluyor. Nereden tutacağını, neresine dokunabileceğini çok iyi anliyorsun zamanla. $\mathrm{K}-3$

Şimdi yenidoğan hemşireliği yani küçük bir bireyle uğraşıyorsunuz, sistemleri küçük, hassaslar, en ufak bir müdahaleniz onlara daha büyük bir yansıma olarak dönebiliyor. $\mathrm{K}-6$

Bebek açısından, damar yolu sıkıntısı yaşayabiliyoruz, özellikle iri bebekler, diyabetli anne bebekleri onlarda damar yolu problemi çok fazla yaşıyoruz veya dışardan gelip damarlar çok fazla tahriş olduğu zaman bizim bulmamız baya zorlaşıyor damar yolunu. $K-1$

Yenidoğanın en büyük problemi kan alma, damar yolu açma. Burada çok ciddi problem olmuyor ama yetişmemiş eleman açısından yenidoğanda ciddi problemler oluyor. Çocuk çok deliniyor. Her girişim, bir ağrıya sebebiyet veriyor. $K-2$

\section{Alt Tema 3. Toparlanma}

Mesela en çok beni makineye bağlı hastanın kısa sürede ekstübe olup hooddan ve oksijenden kısa sürede ayrılması, prematüre bebeklerin güzel kilo alıp toparlaması bu beni çok mutlu ediyor. $K-1$

Orogatrik tüple uzun süre beslenen bebeklerin oral beslenmeye geçmesi gibi bebeğin kısa zamanda kendini toparlayıp taburcu olması, bazen bize geri bildirim olarak bu ailelerin bebekleri bize getirmesi, bunlar bizi ekstra çok mutlu ediyor. $\mathrm{K}-10$

Bir bebek geldiğinde ilk önce o bebeğin sağlığını düzeltmeye yönelik girişimlerde bulunuyoruz doktorlarla beraber ve o bebeğin toparladığını gördükçe yani günden güne düzeldiğini. Güzel olmuş, iyileşmiş, bu bebek gerçekten o mu diye baktığımızda bu şeyler bizi motive ediyor yani mutlu ediyor. Bir birey kazandırmış oluyoruz topluma, sağlıklı bir birey kazandırmış oluyoruz. Bunlar bizi motive eden şeyler. K-8

Annesi ile bebeği oryante edebiliyorsam, ten tene kanguru bakımı yaptırıyorsam, annesine emzirtebiliyorsam orda ekstra bir daha mutlu olabiliyorum. $K-3$

500-600 gramlık bebeklerin doğduğunu onları işte o bakım aşamasında ailesinin kendisinin yaşadığı zorlukları görüp te bunları taburcu ediyoruz; ettikten sonra da bunlar böyle işte hatta birinci sınıfa başlayıp gelenler oluyor ve bunun dönütü gerçekten çok farklı. $K-2$

\section{Tema 2. Yönetim: Aile, ekip, iş yükü}

YYBÜ hemşireleri ile derinlemesine yapılan görüşmelerin içerik analizi sonucu ikinci temanın "Yönetim" ve alt temaların ise aile, ekip, iş yükü olduğu görülmektedir. Aile alt temasının; iletişim, anksiyete, ekip alt temasının; herkesin bir yerden tutması, dikkat, karar verme ve iş yükü alt temasının ise; nöbet sıklığı ve bebek sayısı kodlarından oluştuğu belirlenmiştir (Tablo 1 ). Hemşirelerin çalışma sürecinde çeşitli güçlüklerle karşılaştığı ve bu güçlüklerin önlenebilir nitelikte olduğu belirlendi. YYBÜ'de aile, anne, ekip ve yönetimden kaynaklı olabilen problemlerin, nöbet sıklığının ve bir şiftte bakılan bebek sayısının zaman zaman artmasından kaynaklı iş yükü fazlalığının güçlük nedenleri olduğu ve bunların motivasyonlarını azalttığı belirlendi.

\section{Alt Tema 1. Aile}

Hastane kuralları gereği ailelerle bebeğin medikal durumu hakkında bilgi verme yetkimiz yok. Yani şöyle her gün bilgi alıyor aslında aileler ama, o süreçte muhtemelen atlanan bir şeyler var daha çok tıbbi terimler kullanılıyor muhtemelen onları zaten bilmiyorlar, araştırırken sadece internet üzerinden araştırıyorlar, daha korkunç şeylerle ya da daha basit şeylerle karşılaşıyorlar. Ama bunun geri dönüşü bize oluyor. $\mathrm{K}-3$

Genelde lohusa annelerle uğraştığımız için, bu dönemde çok aşırı duygusal ve panik olabiliyorlar. Bizi en çok uğraştıran şey bu. $\mathrm{K}-\mathrm{T}$

Mesela evden gelen bebekler oluyor 25 günlük filan buraya bir enfeksiyon nedeniyle geliyor. $O$ çocukları da annesiz kesinlikle susturamıyoruz. Çılgınca ağlıyor. Bir de böyle bir problemimiz oluyor. $\mathrm{K}-2$

Annelerin sezaryen sonrası ağrılarının olması, emzirememeleri, sütün belli süre gelmemesinden dolayı bazı sıkıntılar yaşayabiliyoruz. Babaların da sürekli görmek istemesi, büyükannelerin, dedelerin, halaların gelmek istemesi, yasak olduğu halde ısrar etmeleri bunlar bizi biraz sıkıntıya düşürüyor. $K-1$

Bazen annelerin dördüncü beşinci çocuk deneyimi olsa da ilk kez bebek sahibi olmuş gibi yaklaşıyor ve hiçbir şey bilmiyorlarmış gibi davranıyorlar. Bizde onlara sıfırdan her 
şeyi anlatıyoruz. Anne sütü eğitimi, bebeğini tutuşuna, pozisyonuna kadar her şeyi tekrar tekrar anlatıyoruz. K-10

\section{Alt Tema 2. Ekip}

Yenidoğan servisinde ekip önemli. Bebek geldiğinde biz bu bebeği ventilatöre bağlıyoruz bir taraftan, yani hipoksik kalması demek bebeğin beyninde hasar oluşması demek, bunun da yapılması için inanılmaz hızlı olunması gerekiyor ve bir kişi buna mümkün değil yetişemez. O nedenle ekibin kesinlikle iyi olması gerekiyor. Herkesin bir yerden tutması gerekiyor ki o çocuk oksijensiz kalmasın, hasar oluşmasın. Ne kadar erken müdahale, ne kadar erken ısınırsa o çocuk için daha iyi oluyor. $\mathrm{K}-2$

Doktorlar bir order değişikliğine gittiklerinde, eksilen ya da artan ilaç dozları, değişen ilaç miktarları, ilaç adları, bunların peşinde dönüyoruz yani bunu yazmamışsınız bunu çıkarmamışsınız. Bu yani yapılacak mı devam ediyor mu, sürekli uyarı halinde olmamı gerekiyor. Bazen bebeklerin oralı stoplanıyor ve iletmedikleri oluyor. $\mathrm{K}-8$

Alt Tema 3. İs yükü

En fazla arka arkaya nöbetlere gelmek bizi çok fazla yoruyor. Nöbetten çıkıp sonraki gün tekrar nöbete gelmek veya nöbetten çıkıp arada boşluk olmadan gündüze gelmek. Dinlenemeden ve o nöbet bazen ekstra üç dört tane bebek yattığı zaman çok yoruyor. $K-1$

Yani buradaki hastalar ağır hastalar, beslemesini yap, geç, olmuyor. Çoğunluğu solunum sıkıntısılla yatan hastalarımız var, ventile olan hastalarımız var, beslenme bozukluğu, anneler çok ayrı yani, iş yükü çok fazla. $K-8$

Çok yoğun çalışıyoruz, arka arkaya birçok nöbetlerimiz oluyor. Kendimize özel ayırabileceğimiz hiçbir zamanımız yok. $K-2$

Tablo 1. Araştırmanın Temaları

\begin{tabular}{|l|l|}
\hline Temalar & Kodlar \\
\hline Tema 1. Başarı & Annelik duygusu \\
Alt tema 1. Bebek sevgisi & Mutlu olma \\
\hline Alt tema 2. Deneyim & $\begin{array}{l}\text { Karar verme } \\
\text { Özgüven } \\
\text { Dikkat }\end{array}$ \\
\hline Alt tema 3. Toparlanma & $\begin{array}{l}\text { Kilo alıp toparlanma } \\
\text { Günden güne düzelme } \\
\text { Solunum desteğinde azalma } \\
\text { Iyileşme, taburcu olma }\end{array}$ \\
\hline Tema 2. Yönetim & $\begin{array}{l}\text { Iletişim } \\
\text { Anksiyete }\end{array}$ \\
\hline Alt tema 1. Aile & $\begin{array}{l}\text { Herkesin bir yerden tutması } \\
\text { Dikkat } \\
\text { Karar verme }\end{array}$ \\
\hline Alt tema 2. Ekip & $\begin{array}{l}\text { Nöbet sıklı̆̆ı } \\
\text { Bebek sayısı }\end{array}$ \\
\hline Alt tema 3. İ̧ yükü & \\
\hline
\end{tabular}

\section{TARTIŞMA}

YYBÜ'de görev yapan hemşirelerin motivasyonları üzerine yapılan bu çalışmada en dikkat çekici ve duygu yoğunluğu yüksek olan temalardan biri sevgidir. Araştırma kapsamına alınan hemşirelerin tümünün, yenidoğan hemşireliğini ve bebekleri sevmesi motivasyonlarına olumlu katkı sağlayan bir araç olarak değerlendirilmiştir. Motivasyon, bireylerdeki içsel enerjinin belirli hedeflere yönlendirilmesi için hareketlendirilmesi, aktive edilmesidir ${ }^{1-3}$. Hemşirelerin bebeklere yönelik annelik duygusunu da içeren yoğun sevgi ifadeleri, içsel bir enerji olarak onların bir amacı geçekleştirme, aktive olma ve başarılarına aracılık eden önemli bir duygu olarak nitelendirilmiştir. Pediatri hemşiresinin, çocuğun ve tüm aile üyelerinin haklarını koruma ve savunma rolü vardır. Bu nedenle çocukların fiziksel, entelektüel, duygusal, sosyal ve gelişimsel farklılıklarını anlamaları ve çocukları savunmaları için onlara gerekli sevgi ve ilgiyi göstermeleri gerekir ${ }^{21}$ 22. Çocuklarla direkt ilgili olan öğretmenlik gibi diğer mesleklerde de başarı için motive edici bir ortamın ve çocukları sevmenin önemli olduğu belirtilmektedir ${ }^{23-25}$. Bu araştırmanın ilk teması olarak belirlenen "başarı" teması altında incelenen alt temalarda da benzer bulgular elde edilmiştir. Ayrıca, bebekleri başarıya/bir üst sınıfa taşıma sürecinde yapılacak minimal hataların bile geri dönüşü olmayan sorunlara ve bebeğin gelecek yaşantısında olumsuz etkilere yol açabileceği bildirilmiş ve bu konuda deneyimin önemli olduğu hemşireler tarafından vurgulanmıştır. Bry ve Wigert (2021) İsveç'te bir üniversite hastanesinin YYBÜ'de çalışan hemşirelerde $(n=13)$ stres ve sosyal destek üzerine nitel bir araştırma yapmışlardır. Hemşireler, iş yükü ve aile/bebek açısından duygusal olarak zor durumları stres kaynakları olarak tanımlamıştır. Araştırmada deneyimsiz hemşirelerin işlerini oldukça zor buldukları ve deneyimli meslektaşlarının yardımına bağımlı oldukları, bu nedenle olumlu çalışma ikliminin ve akran desteğinin önemli olduğu sonucuna varılmıştır ${ }^{26}$. Literatürde yer alan çalışmalar, hemşirelerin kazandıkları deneyim ve özgüven ile, anksiyete düzeylerinin azaldığı ve kendileri hakkındaki olumsuz duyguları ortadan kalktığı için klinik karar verme üzerinde de olumlu bir etki sağladığını göstermektedir ${ }^{27,28}$. Benzer bir sonuç olarak bu çalışmada da hemşirelerin, deneyim, özgüven, klinik karar verme, dikkat ve sevginin olduğu bu ortamda bebeklerin iyileşmeleri, ağırlık kazanımları ve solunum desteği gereksiniminin azalarak taburculuğa hazırlanmasında kendilerinin önemli rol oynayarak mutlu oldukları, başarı duygularının ve motivasyonlarının arttığı belirlendi. Literatüre bakıldığında hemşirelerin motivasyonlarına yönelik nitel araştırmaların sınırlı olduğu daha çok nicel araştırma tasarımının yer aldığı görülmüştür. Çelik ve Karaca (2017) tarafından yapılan hemşirelerde yapılan bir çalışmada bu çalışma ile benzer olarak "Motivasyon Ölçeği”nden en yüksek puanı "İşimi severek yapıyorum" maddesinin yer aldığı bulunmuştur ${ }^{16}$. Diğer bir çalışmada pediatri hemşirelerinin mesleki değer algılarının iş doyumuna pozitif yönde etkisinin olduğu bulunmuştur ${ }^{29}$. Diğer bir çalışmada ise pediatri hemşirelerinin çocuk sevme puanları arttıkça mesleki doyumlarının arttığı, tükenmişlik ve eşduyum yorgunluğunun azaldığı saptanmıştır ${ }^{30}$. Öğretmen ve öğretmen adaylarına yönelik yapılan çalışmalarda ise çocuk sevme puanlarının, öğrenme motivasyonları puanlarını anlamlı düzeyde yordadığı belirlenmiştir ${ }^{24,25}$.

Hastanın hastaneye girişinden taburculuğa kadar geçen sürede sunulan sağlık hizmeti, ekip çalışmasına temellidir ${ }^{14}$. 
Motivasyon ise bir ekibin başarısını etkileyen en önemli faktörlerden biridir. Ekip çalışmasının benimsenmesi ile işletmeler bir yandan çalışanlarının motivasyonlarını arttırırken örgüt içerisindeki iletişim kopukluklarını ortadan kaldırmakta sonuçta sağlık hizmetlerinde hasta/ailelerin gereksinimleri de yeterli oranda karşılanabilmektedir ${ }^{31}$. YYBÜ'de çalışan hemşirelerinin motivasyonlarının incelendiği bu çalışmada da hemşirelerin çalışma ortamında zaman zaman güçlük yaşadıkları, bu güçlüklerin motivasyonlarını azalttığı belirlenmiştir. YYBÜ'de aileler, sağııkı bir bebek beklerken erken doğmuş ve/veya fiziksel gelişim bozukluğu olan bir bebeğin doğumu ile kayıp yaşadıkları, anne-bebek bağlanmasının güçleştiği, yeni rollerine uyum sağlamaları beklenen bu süreçte sağlık ekibinin deneyimli tedavi ve bakımının yanı sıra uygun bir iletişime de gereksinim duyarlar9,21,22,32,33. Merkezinde aile/hastanın olduğu bir ekip çalışmasının benimsenmesi, hasta güvenliğinin sağlanması, bakım kalitesinin arttırılması için insan yaklaşımının yanı sıra sistem yaklaşımına da odaklanılması önemli bir adımdır. Sistem yaklaşımından kaynaklanan güçlükler, güvenli çalışma iklimi, etkili ekip çalışması ve işbirliği, hasta güvenliği kültürünün kurumsallaştırılması, aile merkezli bakım ve kanıta dayalı uygulama gibi temel bilimsel yöntemler sayesinde önlenebilir ${ }^{14,32,33}$. Özellikle salgın sürecinde motive edici bir ortam sağlamada, hastane yönetimi ile birlikte yönetici hemşirelerin, iş yükü, çalışanların kararlara katılımı, uygun fiziki koşullar, yeterli araç-gereç, geliştirme ve kariyer planlama, sosyal haklar, iş sağlığı ve güvenliği, ekip iş birliği, iletişim, takdir ve tanınma, etkili yönetim ve liderlik konularında önemli sorumlulukları olduğu bildirilmektedir ${ }^{34}$. Hastane gibi insan hayatını doğrudan etkileyen kurumların vardiyalı çalışanlarının sağlık ve iyilik halini doğrudan etkileyen uyku kalitesini artırmaya yönelik önlemlerin, hem kurum bazında hem de yasalar tarafından güvence altına alınmasının önemli olduğu belirtilmiştir ${ }^{35}$. Sasso ve ark. (2019) İtalya'da 3667 hemşirenin dahil edildiği kesitsel bir araştırmada hemşirelerin \%33.1'inin yetersiz personel ve iş yüküne bağı mesleki doyum yetersizliği nedeniyle meslekten ayrılmayı istediklerini belirlemişlerdir ${ }^{36}$. Bu çalışmada da hemşirelerin motivasyonlarını azalttığı belirlenen iş yüküne yönelik güçlüklerin çoğunluğunun sistem kaynaklı oluştuğu dikkat çekmiştir. Acil servis hemşirelerinin bakım algılarının nitel olarak analiz edildiği bir çalışmada ise hemşirelerin bu çalışma ile benzer olarak yoğunluk, iş yükü ve sirkülasyonun fazla olması ile bakım gereksinimlerini yerine getiremedikleri belirlenmiştir. Aynı çalışmada elde edilen sonuçlar doğrultusunda; hemşirelerin bakım sağlayıcı rollerini olumsuz etkileyen çalışma saatleri, hemşire sayısı gibi faktörlerin iyileştirilmesine yönelik kurumsal planlamaların yapılması önerilmektedir ${ }^{37}$. Pediatri hemşirelerinde tükenmişlik üzerine yapılan sistematik bir derlemede ise tükenmişliğin yaygın bir problem olduğu, hemşirelik okulları, hemşirelik yönetimi, sağlık kuruluşları ve hemşirelik meslek birlikleri tarafından hemşirelerde tükenmişliği azaltmak amacıyla girişimsel çalışmalar yapılmasının önemi vurgulanmıştır ${ }^{38}$.

\section{SONUÇ ve ÖNERILER}

Hemşirelerin bebek sevgisinin, deneyimli hemşirelik bakımı ve izlem ile onların iyileşme bulguları göstermesinin başarı duygularını ve motivasyonlarını arttırdığı ancak ekip, iletişimden kaynaklı sorunlar ve iş yükünün getirdiği güçlüklerin motivasyonlarını azalttığı belirlenmiştir. Çözümlenebilir nitelikte olan bu güçlüklerin ve sistem/yönetim kaynaklı sorunların minimalize edilmesi için ekip çalışmasının benimsenerek hemşirelerin motivasyonlarının desteklenmesi gerekmektedir. Ayrıca, gebelik, doğum, annelik gibi rol değişimlerinde bireylerle en sık etkileşim içinde olan hemşirelerin motivasyonlarının arttırılmasına yönelik farklı nitel araştırmaların, deneysel tasarımlı çalışmaların yapılarak literatüre kazandırılması ve sağlık ekibinde yer alan diğer sağlık profesyonellerinin de dahil edildiği araştırmaların yapılması önerilmektedir.

Etik Kurul Onayı: Tokat Gaziosmanpaşa Üniversitesi Sosyal ve Beşeri Bilimler Araştırmaları Etik Kurulu'ndan onay alınmıştır (Karar No:01-11, Karar Tarihi: 05.06.2020).

Çıkar Çatışması: Bildirilmemiştir.

Finansal Destek: Yoktur.

Katılımcı Onamı: Katılımcılardan bilgilendirilmiş onam alınmıştır.

Yazar katkıları:

Araştırma dizaynı: MDA, EB

Veri toplama: MDA

Veri analizi: $M D A, E B$

Makale yazımı: MDA, EB

Teşekkür

Yazarlar araştırmaya katılmayı kabul eden tüm hemşirelere teşekkürlerini sunar.

Ethics Committee Approval: Approval was obtained from Tokat Gaziosmanpaşa University Social Sciences and Humanities Research Ethics Committee (Decision number: 01-11, Decision date:05.06.2020).

Confict of Interest: Not reported.

Funding: None.

Exhibitor Consent: Informed consent was obtained from participants.

Author contributions:

Study design: MDA, EB

Data collection: MDA

Data analysis: MDA, EB

Drafting manuscript: MDA, EB

Acknowledgement: We would like to thank all nurses who approved to participate to the study.

\section{KAYNAKLAR}

1. Tarakçıoğlu S, Sökmen A, Boylu Y. Evaluation of motivation factors: A research in Ankara. Işletme Araştırmaları Dergisi. 2010;2(1):3-20.

2. Cumbler E, Kneeland $P$, Hagman J. Motivation of participants in an interprofessional quality improvement leadership team. Journal of Interprofessional Education \& Practice. 2016;3:5-7.

3. Tunçer P. Örgütlerde performans değerlendirme ve motivasyon. Sayıştay Dergisi. 2013;88:87-90.

4. Örücü $E$, Kanbur A. Örgütsel-Yönetsel motivasyon faktörlerinin çalışanların performans ve verimliliğine 
etkilerini incelemeye yönelik ampirik bir çalışma: Hizmet ve endüstri işletmesi örneği. Yönetim ve Ekonomi. 2008;15(1):85-97.

5. Ünaldı Türkkan N, Eşkin Bacaksız F, Tuna R. Hemşirelik Hizmetleri Yönetimi. İstanbul: Akademi Basın ve Yayıncılık; 2014.

6. Özsoylu S, Akyıldız B, Dursun A. Bir üniversite hastanesinde çalışan hemşirelerin tükenmişlik düzeyi ve etkileyen faktörler. J Pediatr Emerg Intensive Care Med. 2017;4:104-09.

7. Sullivan R, Perry R, Sloan A, Kleinhaus K, Burtchen N. Infant bonding and attachment to the caregiver: Insights from basic and clinical science. Clin Perinatol. 2011;38(4):643-55.

8. Köse D, Çınar N, Altınkaynak S. Yenidoğanın anne ve baba ile bağlanma süreci. Sted. 2013;22(6):239-45.

9. Demir Acar M, Yılmaz U, Çevik Güner Ü. Bebeği konjenital anomalili doğan annenin anne-bebek bağlanmasında yaşadığı güçlükler ve hemşirenin rolü. Turkiye Klinikleri J Nurs Sci. 2018;10(2):169-76.

10. Turhal A, Karaca A. Bebeği yenidoğan yoğun bakım ünitesinde tedavi altında olan annelerin yaşadıkları psikososyal sorunlar ve başa çıkma yöntemlerinin belirlenmesi: Niteliksel bir araştırma. Düzce Üniversitesi Sağlık Bilimleri Enstitüsü Dergisi. 2019;9(3):172-80.

11. Korukcu O, Deliktaş A, Kukulu K. Transition to motherhood in women with an infant with special care needs. Int Nurs Rev. 2017;64(4):593-601.

12. Doğanlı B, Demirci Ç. Sağlık kuruluşu çalışanlarının (hemşire) motivasyonlarını belirleyici faktörler üzerine bir araştırma. Yönetim ve Ekonomi. 2014;21(1):47-60.

13. Hakmal $H$, Karadağ $M$, Demir $C$. Hemşirelerin motivasyon düzeylerine etki eden faktörler: Gülhane Askeri Tıp Fakültesi Eğitim Hastanesinde bir uygulama. Anadolu Hemşirelik ve Sağlık Bilimleri Dergisi. 2012;15(3):181-87.

14. Çiçek Korkmaz A. Hasta güvenliğinde sistem hataları ve hemşirelik yaklaşımı. Yıldırım Beyazıt Üniversitesi Sağlık Bilimleri Fakültesi Hemşirelik E-Dergisi. 2015;3(2):4855.

15. İlhan A, İnce E. Takım çalışması ve takım etkinliğini belirleyen faktörlerin ölçülmesi: Gaziantep Üniversitesinde bir uygulama. Kahramanmaraş Sütçü İmam Üniversitesi İktisadi ve İdari Bilimler Fakültesi Dergisi. 2015;5(1):127-52.

16. Çelik A, Karaca A. Hemşirelerde ekip çalışması ve motivasyon arasındaki ilişkinin ve etkileyen faktörlerin değerlendirilmesi. Hemşirelikte Eğitim ve Araştırma Dergisi. 2017;14(4):254-63.

17. Karataş Z. Sosyal bilimlerde nitel araştırma yöntemleri. Manevi Temelli Sosyal Hizmet Araştırmaları Dergisi. 2015;1(1):62-80.

18. Türnüklü $A$. Eğitim bilim araştırmalarında etkin olarak kullanılabilecek nitel bir araştırma tekniği: Görüşme. Kuram ve Uygulamada Eğitim Yönetimi Dergisi. 2000;6:543-59.

19. Yıldırım A. Şimşek H. Sosyal Bilimlerde Nitel Araştırma Yöntemleri. 9. Baskı, Ankara: Seçkin Yayıncılık; 2013.
20. Başkale H. Nitel araştırmalarda geçerlik, güvenirlik ve örneklem büyüklüğünün belirlenmesi. Dokuz Eylül Üniversitesi Hemşirelik Fakültesi Elektronik Dergisi. 2016;9(1):23-8.

21. Hockenberry MJ, Wilson D. Wong's Nursing Care of Infants and Children. Ninth Edition, America: Elsevier Mosby Company; 2011.

22. Çavuşoğlu H. Çocuk Sağlığı Hemşireliği. 11. Baskı, Ankara: Sistem Ofset Basımevi; 2013.

23. Yazıcı Z. The Examination of pre-school teachers' towards liking of children. Procedia-Social and Behavioral Sciences. 2014;116:172-6.

24. Ilğan A, Canoğlu Ö, Karamert Ö, Şensoy ÇP. Öğretmenlerin çocuk sevme düzeyleri ile öğretme motivasyonları arasındaki ilişkinin incelenmesi. Turkish Studies Educational Sciences. 2018;13(19):979-1003.

25. Dereli İman E. Okul öncesi öğretmen adaylarının çocuk sevgisi ve öğretmenlik mesleğine ilişkin motivasyonlarının incelenmesi. Journal of Theoretical Educational Science. 2014;7(4);482-504.

26. Bry A, Wigert $H$. Stress and social support among registered nurses in a level II NICU. Journal of Neonatal Nursing. (in press). 2021. https://doi.org/10.1016/j.jnn.2021.03.010

27. Espinosa-Rivera BP, Morán-Peña L, García-Piña MA, González-Ramírez P, López-Ruíz CM. Self-confidence and anxiety as intervening factors in clinical decisionmaking in newly nursing bachelor graduates. American Journal of Nursing. 2019;8(2):59-67.

28. White KA. Development and validation of a tool to measure self-confidence and anxiety in nursing students during clinical decision making. Journal of Nursing Education. 2014;53(1):14-22.

29. Kaya A, Çelik D, iş̧ler Dalgıç A. Professional values and job satisfaction levels of pediatric nurses and influencing factors: A crosssectional study. J Pediatr Res. 2020;7(1):58-63.

30. Çalışır $H$, Karataş $P$, Turan $T$, Ergin E. Pediatri hemşirelerinde çocuk sevme ile tükenmişlik, eşduyum yorgunluğu, mesleki tatmin arasındaki ilişki. Turkiye Klinikleri J Nurs Sci. 2020;12(1):30-36.

31. Özler E, Koparan E. Takım performansına etki eden takım çalışmasına ilişkin faktörlerin belirlenmesine yönelik bir araştırma. Uluslararası Hakemli Sosyal Bilimler E-Dergisi. 2006;8:1-29.

32. Reid S, Bredemeyer S, Chiarella M. The evolution of neonatal family centred care. Journal of Neonatal Nursing. (in 2021. https://doi.org/10.1016/j.jnn.2021.03.002

33. Loewenstein K, Barroso J, Phillips S. The experiences of parent dyads in the neonatal intensive care unit: A qualitative description. Journal of Pediatric Nursing. 2021;60:1-10.

34. Duygulu S, Başaran Açıl S, Kuruca Özdemir E, Erdat Y. COVID-19 salgını: Yönetici hemşirelerin rol ve sorumlulukları. Hacettepe Üniversitesi Hemşirelik Fakültesi Dergisi. 2020; Özel sayı (7):34-46.

35. Bumin G, Tatı IY, Cemali M, Kara S, Akyürek G. Vardiyalı ve gündüz çalışan sağlık çalışanlarında uyku kalitesi, 
reaksiyon zamanı, stres ve iyilik halinin karşılaştırılması. Hacettepe Üniversitesi Hemşirelik Fakültesi Dergisi. 2019;6(3):189-96.

36. Sasso L. Bagnasco A, Catania G, Zanini M, Aleo G, Watson $R$ et al. Push and pull factors of nurses' intention to leave. Journal of Nursing Management. 2019;27(5):946-54.

37. Ince $S$, Bingöl S. Acil serviste çalışan hemşirelerin hemşirelik bakım algıları. Hacettepe Üniversitesi Hemşirelik Fakültesi Dergisi. 2020;7(1):23-30.

38. Buckley L, Berta W, Cleverley K. Medeiros C, Widger K. What is known about paediatric nurse burnout: a scoping review. Hum Resour Health. 2020;18(9):2-23. 